\title{
Erratum to: An Intense Green Emission From ZnO Nanoparticles Coated with MgO
}

K. Sowri Babu, A. Ramachandra Reddy and K. Venugopal Reddy

\section{Erratum to:}

Chapter 223 in: V.K. Jain and A. Verma (eds.), Physics of Semiconductor Devices,

DOI 10.1007/978-3-319-03002-9_223

The whole chapter 'An Intense Green Emission From $\mathrm{ZnO}$ Nanoparticles Coated with MgO' by K. Sowri Babu, A. Ramachandra Reddy, K. Venugopal Reddy in Physics of
Semiconductor Devices (2014), (pp. 869-871) is retracted based on author's request.

The online version of the original chapter can be found under DOI 10.1007/978-3-319-03002-9_223

K. Sowri Babu $(\square) \cdot$ A. Ramachandra Reddy

K. Venugopal Reddy

Department of Physics, Materials Science Laboratory,

National Institute of Technology Warangal, Warangal 506004,

Andhra Pradesh, India

e-mail: sowribabuk@gmail.com 